\title{
A Macro Analysis of Bank Performance in Debt-Burdened Countries: The Case of Nigeria
}

\author{
Obademi Olalekan Emmanuel \\ Department of Finance, University of Lagos, Nigeria
}

\begin{abstract}
In this study the focus is on the long-run relationship and impact of public debt on banking industry performance i.e. a macro-analysis in Nigeria using different performance indices such as total bank lending, total bank deposit and total bank branches between the period1975-2005. A general macro model underpinned by a simultaneous equation using a vector auto-regression estimation approach was done with the objective of sensitising countries on the need for caution on public debt. The findings are that public debt impacts negatively on bank performance but the extent of impact is different on the variables chosen in this study. The analysis carried out show that domestic debt impacts most negatively on total bank lending while external debt impacts most negatively on total bank deposit. It is believed that though domestic debt can be used as an instrument of economic stabilization, nonetheless, in the choice of whether to use domestic debt or external debt it may be more expedient to use external debt based on the outcome of this study though it should be stated that in doing that still, adequate care must be taken to maintain an acceptable Debt/GDP ratio needed for debt sustainability.
\end{abstract}

Keywords: Domestic debt, external debt, bank performance, total bank lending, total bank deposit

\section{Introduction}

The issue of public debt in Nigeria has dominated the media space in recent times in Nigeria as it was prior to the debt forgiveness which Nigeria secured in year 2005 from her prominent foreign creditors. The size of public debt will affect individual citizens, institutions of government, privately owned corporate organizations like banks and consequently the economy at large. With basic economic knowledge it should be understood that the nature and size of public debt will affect the performance of the banking sector but the direction and extent of impact especially from the industry perspective has not been exhaustively researched into. Debt according to Oyejide (1985) refers to the resource or money in use by an organization or nation which is not contributed by the user or does not in any way belong to the country.

The focus on public debt and banking sector performance is not misplaced because expectedly there is a causal relationship between the wellbeing of a nation and sectors within it especially the banking sector. According to Hugh (1996) the contribution of the financial sector to development is a function of the quantity and quality of its services and the efficiency with which the services are being provided. The sector is expected to facilitate the flow of financial services that has the capacity to give rise to a supply-led policy that advances production in the real sector. There is a general convergence of views that the financial sector of an economy and the by implication the banks are essential to economic development. In concrete terms and according to literature, banks facilitate capital formation and accumulation which is necessary for the smooth running of an economy but public debt impairs and frustrates the ability of banks to enhance capital formation in debtor countries.

In addition, public debt affects the capital structure of banks by hampering attainment of an optimal capital structure which thus affects bank's performance accentuated by exchange rate volatility that characterises an economy with a high debt profile by hampering the intermediation function of banks and their role in facilitating foreign direct investment. Traditionally, a highly leveraged banking firm faces higher risks than a well capitalized bank hence such banks stand the risk of corporate failure according to Adenikiju (2009)

Also, in their study, Ncube and Senbet (1994) affirmed that an efficient financial system is germane to domestic capital formation and promotes competitive advantage in the global market for capital. However, high debt profile which is an evidence of an economy in crisis discourages savings which by extension affects bank's performance. For the mere fact that public debt depresses the capacity to save by citizens, banks are often forced to access high risk funds that increases their risk exposure consequent upon distortions introduced into the financial system as a result of a country's high debt profile.

This study carried out using Nigeria as an example is instructive going by the fact that for a long time before the debt relief granted Nigeria in year 2005, the country was under intense debt crisis and passed for a debt burdened nation whose debt stifled growth and development in critical sectors of 
the economy. Nigeria being a developing country, it is expected that the issues highlighted, analysed and discussed in this study will enable other countries especially those in Sub-Sahara Africa exercise reasonable caution in dealing with public debt issues.

\section{Literature Review}

Several researches have been conducted on the subject of public debt in general and its impacts on countries' welfare from the perspective of economic growth but there are few sector specific studies especially focusing on Sub-Sahara African countries. In adducing the reasons for incurring debt especially as it concerns external debt, Soludo (2001) posited that external borrowing is connected with three phases of the debt cycle; in the first phase, debt grows in order to fill resource gaps and in the second phase the country generates resource surplus but probably not enough to offset interest payments while in the third phase it must generate enough surplus to cover interest payments and amortization. He stated however that the peculiar experience of highly indebted poor countries (HIPC) is that they have been trapped in the first and second phases for many years.

In the same vein, Ahmad (1999) stated that though large foreign and domestic debt on a country can pose serious economic problems, foreign debt is usually created to sustain a growth rate of the economy that is otherwise not feasible within the given pool of domestic resources and in the light of existing level of technology, consumption propensity and economic management practices and likewise, domestic debt measures the cost of maintaining a large public sector profile. While also Fajana (2003) sees nothing wrong with external or foreign borrowing he however insisted that debt arose due to the mismanagement of loan funds. He believes that borrowing is desirable and inevitable because external borrowing is the first order condition for bridging the domestic resource gap, and the second order condition is that funds be invested on viable projects whose rate of return is higher than that of the interest on the loan. He summed it up by saying that for foreign loans to serve as engine of growth, it has to be well managed and the resources it makes available needs to be prudently and efficiently used. The trade-off relationship between foreign capital and economic growth has been studied in the framework of traditional neo-classical growth models by Ahmad and Paul (1997), Ahmad and Crouch (1997). This relationship and the implication of domestic public debt has also been discussed in the framework of overlapping generation models like Samuelson (1958), Diamond (1965), and Willis (1983). Now with reference to the impact of debt Borensztein (1990) in his study found that debt overhang has an adverse effect on private investment in the Philippines. The effect was strongest when private debt rather than total debt was used as a measure of debt overhang. Iyoha (1996) was also of the opinion that heavy debt burden acts to reduce investment through both debt overhang and the crowding out effect especially in Sub-Saharan African countries. This position was reinforced by Foxley (1987) who posited that foreign debt has the capacity to crowd out domestic saving.

Chapple (1990) posited that explosive increases in both deposit and loan rates which is a major feature of an economy in crisis mostly by huge debt/ debt overhang will impact negatively on the profit margins of banks as people will be discouraged from investing. On the other hand according to De Young, Gron and Winton (2005) in periods of economic expansion demand for lending is often high being an extension of overall business profitability. The scenario under this is that there will be more profitable loans, more bank capital and an expanding credit environment in which financial institutions mainly banks lend more at lower rates but with larger volumes of business and thus higher profitability.

In order to effectively manage the distortions in the economy due to the high debt profile in Nigeria various policy changes and reforms have been introduced that affected lending one way or the other especially the monetary policy thrust of the government that impacts on banks directly. Van den Henvel (2005) asserted that monetary policy affects bank lending through two channels. He posited that monetary policy has a direct effect on the supply reserve requirements as a decrease in reserve liabilities he said will lead reduction in lending.

Against the backdrop of the public debt crisis Imala (2005) referring to the apathy of banks towards small savers said the structure of the banking sector then promoted tendencies that produce a rather sticky behavior of deposit rates particularly at the retail level such that banks lending rates remain high and positive in real terms while most deposit rates especially for saving were low. In this study, the aim then is to see in real quantitative terms how bank performance was affected before the debt relief using total bank lending, total bank deposit and total bank branches as measures of performance.

\section{Methodology}

This study analyses quantitatively the long-run equilibrium relationship and impact of public debt on banking sector performance at the industry level using total bank deposit and total bank branches. Herein, a macro-approach has been used within the framework of simultaneous equations. The variables for the macro-analysis are the total bank lending, the total bank deposit and the total bank branches. According to Santos (2000) conventional banking theories assume that banks earn profits by 
purchasing transactions deposits from depositors at a low interest rate and reselling those funds to borrowers at higher interest rate based on its competitive advantage at gathering information and underwriting risk. In other words conventional banks make profits from the spread between interest rates received from borrowers and the interest paid to depositors and the capability by which this is done can be used to measure a bank's performance from the aforementioned perspectives.

The macro model is based on the Extreme Bound Analysis proposition as developed by Levine and Renelt (1992) and also used by Busari (2001) while looking at the impact of debt on growth with a background perspective of neoclassical model of savings which involves the estimation of a regression of a linear function. The general model of the macro-approach is expressed as:

$\mathrm{BPM}=\mathrm{f}($ Debt $)$

The proxies for the macro-analysis are as expressed hereunder:

$\mathrm{BPM}=\mathrm{TBB}, \mathrm{TBL}, \mathrm{TBD}$

$\mathrm{Debt}=\mathrm{TDB}, \mathrm{EDB}, \mathrm{DDB}$

Where,

BPM is Bank Performance

TBB is Total Bank Branches

TBL is Total Bank Lending

TBD is Total Bank Deposit

Hence,

$\mathrm{BPM}=\mathrm{a}_{1}+\mathrm{a}_{2} \mathrm{TDB}+\mathrm{a}_{3} \mathrm{EDB}+\mathrm{a}_{4} \mathrm{DDB} \ldots \ldots \ldots \ldots \ldots .4 .4$

$\mathrm{TDB}=\mathrm{b}_{1}+\mathrm{b}_{2} \mathrm{EDB}+\mathrm{b}_{3} \mathrm{DDB}+\mathrm{b}_{4} \mathrm{BPM} \ldots \ldots \ldots \ldots . . . . .3$

$\mathrm{FDB}=\mathrm{c}_{1}+\mathrm{c}_{2} \mathrm{TDB}+\mathrm{c}_{3} \mathrm{DDB}+\mathrm{c}_{4} \mathrm{BPM} \ldots \ldots \ldots . .3 .6$

$\mathrm{DDB}=\mathrm{d}_{1}+\mathrm{d}_{2} \mathrm{TDB}+\mathrm{d}_{3} \mathrm{EDB}+\mathrm{d}_{4} \mathrm{BPM} \ldots \ldots \ldots \ldots . . \ldots . . \ldots$

TDB is the total debt while DDB is domestic debt and EDB is the foreign debt/external debt

\section{A priori expectations}

The a priori expectation in this study is that public debt will depress the performance of the banking sector and this has to be ascertained. What is not known is the magnitude of the impact of the debts in general on the industry.

\section{Estimation technique}

In this study, a stationarity test using the unit root approach was first conducted to confirm whether a long run equilibrium relationship exists among the variables to justify the use of co-integration technique, however the result showed that all the variables are integrated of different order. The implication of this is that the necessary condition for the use of cointegration has not been fulfilled hence the Vector Auto regression technique (VAR) was found to be a better alternative and thus used. VAR is a widely used econometric technique for multivariate time series modeling and provides a tool for analyzing the dynamics of variables in a standard spatial auto regressive modeling. It shows considerable predictive ability and helps in defining evidence in terms of long run relationship between variables.

The underlying principle for using this macroapproach also align with the concept of the use of the Canonical Correlation Analysis (CCA) which helps in capturing both endogenous and exogenous variables that influence bank performance as was used by Arshadi and Lawrence (1987). With this type of analysis, various measures of performance can be simultaneously related to a set of external and internal variable critical to bank performance. Canonical correlation analysis is a method of correlating linear relationships between two multidimensional variables. With CCA, various measures of performance can be simultaneously related to a set of external and internal variables which influence performance. Canonical correlation analysis can be seen as using complex labels as a way of guiding feature selection towards the underlying semantics because CCA makes use of two views of same semantic object to extract the representation of semantics. The estimation technique for the general macro-model is expressed as:

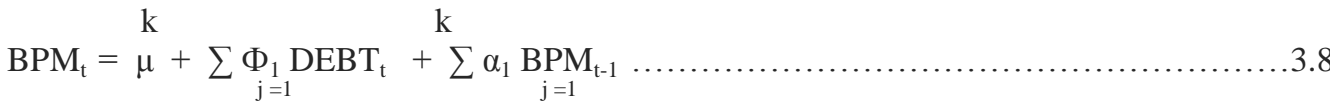

$$
\begin{aligned}
& \text { k k } \\
& \operatorname{DEBT}_{\mathrm{t}}=\mu+\sum \underset{\mathrm{j}=1}{\Phi_{2}} \mathrm{BPM}+\sum \alpha_{2} \mathrm{DEBT}_{\mathrm{j}=1}
\end{aligned}
$$

This is further expressed as:

$$
\begin{aligned}
& \text { k } \mathrm{k} \quad \mathrm{k} \quad \mathrm{k} \\
& \mathrm{BPM}_{\mathrm{t}}=\mu+\sum \underset{\mathrm{j}=1}{\Phi_{\mathrm{j}}} \mathrm{TDB}_{\mathrm{j}-1}+\sum \underset{\mathrm{t}=1}{\beta \mathrm{FDB}_{\mathrm{t}-1}}+\sum \Phi_{\mathrm{p}} \mathrm{DDB}_{\mathrm{p}-1}+\sum \alpha_{\mathrm{t}} \mathrm{BPM}_{\mathrm{t}-1}+\underset{\mathrm{t}=1}{\epsilon_{\mathrm{t}}} \ldots \\
& \text { k k k k }
\end{aligned}
$$

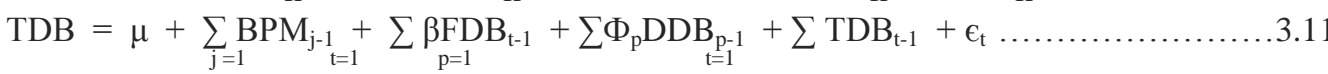

$$
\begin{aligned}
& \mathrm{k} \quad \mathrm{k} \quad \mathrm{k} \quad \mathrm{k} \\
& \mathrm{FDB}=\mu+\sum_{\mathrm{j}=1} \mathrm{BPM}_{\mathrm{j}-1 \mathrm{t}=1}+\sum \underset{\mathrm{p}=1}{\beta \mathrm{TDB}_{\mathrm{t}-1}}+\sum_{\mathrm{t}=1} \Phi_{\mathrm{p}} \mathrm{DDB}_{\mathrm{p}-1}+\sum \mathrm{FDB}_{\mathrm{t}-1}+\epsilon_{\mathrm{t}} \ldots \\
& \text { k k k k } \\
& \mathrm{DDB}=\mu+\sum \mathrm{BPM}_{\mathrm{j}-1}+\sum \beta \mathrm{TDB}_{\mathrm{t}-1}+\sum \Phi_{\mathrm{p}} \mathrm{FDB}_{\mathrm{p}-1}+\sum \mathrm{DDB}_{\mathrm{t}-1}+\epsilon_{\mathrm{t}} \ldots
\end{aligned}
$$


Following the objectives of the study and being a time series analysis, the Vector Autoregressive (VAR) technique has been used to determine the nature of the relationship between Nigeria's debt burden and all variables representing banking sector performance in a simultaneous manner. Vector Auto-regression is a widely used econometric technique for multivariate time series modeling. VAR provides a valuable tool for analyzing the dynamics of variables in a standard spatial autoregressive modelling. This is because it makes it possible to analyze the interactions among the variables used in the model more adequately. VAR shows considerable predictive ability and helps in defining evidence in terms long run relationship between variables.

Vector Autoregression is one of the most successful, flexible and easy to use technique for the analysis of multivariate time series. It is a natural extension of the univariate autoregressive model to dynamic multivariate time series. This VAR model has proven to be especially useful for explaining the dynamic behaviour of economic and financial time series and for forecasting. It usually provides superior forecasts to those from univariate time series models and elaborate theory based simultaneous equation models. Forecasts from VAR models are quite flexible because they can be conditional on the potential future paths of specified variables in the model. Here apart from data description and forecasting, VAR is also used for structural inference and policy analysis. In structural analysis, certain assumptions about the causal structure of the data under investigation are imposed and the resulting causal impacts of unexpected shocks and innovations to specified variables on the variables in the model are summarized. These causal impacts are usually summarized with impulse response functions and forecast error variance decomposition.

Generally, VAR as an econometric tool is used to capture the evolution and interdependence between multiple time series, generalizing the univariate auto-regression models. All variables in a VAR are often treated symmetrically by including for each variable an equation explaining its evolution based on its own lags and the lags of all other variables in the model. Hence VAR many times as in this case becomes a handy practical method useful in estimating economic relationships and thus a better alternative to the incredible identification restrictions in structural models. Herein in this study VAR is thus used to analyze the dynamic impact of random disturbances on the system of variables.

Debt burden variables are the domestic debt (DDB), external debt (EDB) and the total debt values (TDB), while the variables representing banking sector performance (BPM) in this study are:

TBD $=$ Total Bank Deposit

TLD $=$ Total Lending

$\mathrm{TBB}=$ Total Bank Branches

The lag lengths are chosen using Akaike information criterion (AIC), $\varepsilon_{t}$ is known as the impulse innovation or shocks in the language of VAR. The estimate of VAR has been used to determine or trace the effect of one standard deviation shock to one of the innovations on current and future values of the endogenous variables. This analysis is called "Impulse response analysis". Also a different method of depicting the system dynamics is to decompose the variations in total debt burden variable into the component shocks to the banking sector performance variables in the VAR; this analysis is called "Variance decomposition". The analysis is basically a macroanalysis that looks at the entire industry. This thus gives a basis for a deeper understanding and comparison of the impact of debt on the banking sector.

\section{Var analysis of the macro-model}

The major objective under this analysis is to determine the true nature of the relationship between Nigeria's debt burden and banking sector performance. One advantage of the VAR over the cointegration analysis is that it assumes all variables are endogenous and analyze a simultaneity relationship among the variables, such that the direction of causality and exogeneity is clearly shown by the result. The result of the VAR estimates for the macromodel are presented below. In VAR analysis, the estimated coefficients of the lags may not have any economic interpretation but the $\mathrm{R}^{2}$ and adjusted $\mathrm{R}^{2}$ all serve to show the levels of exogeneity, while distributions of impact (shocks) is clarified by the variance decomposition.

\section{Empirical Results}

Table 1. Correlation matrix of variables in the model.

\begin{tabular}{lcccccc}
\hline & DDB & EDB & TDB & TBB & TBD & TBL \\
\hline DDB & 1.000 & 0.95 & 0.97 & 0.78 & 0.95 & 0.94 \\
EDB & 0.95 & 1.000 & 0.99 & 0.74 & 0.88 & 0.84 \\
TDB & 0.97 & 0.99 & 1.00 & 0.76 & 0.91 & 0.88 \\
TBB & 0.78 & 0.74 & 0.76 & 1.000 & 0.67 & 0.65 \\
TBD & 0.95 & 0.88 & 0.91 & 0.67 & 1.000 & 0.99 \\
TBL & 0.94 & 0.85 & 0.88 & 0.65 & 0.99 & 1.000 \\
\hline
\end{tabular}


Table 2. Philip Peron unit root test summary.

\begin{tabular}{lcccc}
\hline \multicolumn{1}{c}{ Series } & PP Test Start & $1 \%$ C.V & $5 \%$ C.V & Integration \\
\hline D (TBL,2) & -10.2814 & -3.6852 & -2.9705 & I $(2)$ \\
D(TBD,2) & -13.9997 & -3.6852 & -2.9705 & I $(2)$ \\
DTBB & -5.1710 & -3.6752 & -2.9665 & I $(1)$ \\
DTDB $(2)$ & -4.4761 & -3.6852 & -2.9705 & I $(2)$ \\
D(EDB,2) & -4.4977 & -3.6852 & -2.9705 & I $(2)$ \\
D(DDB,2) & -6.5338 & -3.6852 & -2.9705 & I $(2)$ \\
D(ROEF) & -5.4027 & -3.6752 & -2.9665 & I $(1)$ \\
D(ROEU) & -5.3503 & -3.6752 & -2.9665 & I $(1)$ \\
D(ROCEU) & -4.3919 & -3.6661 & -2.9627 & I $(1)$ \\
D(ROCEF) & -4.8849 & -3.6661 & -2.9627 & I $(1)$ \\
D(EPSU) & -5.9808 & -3.6752 & -2.9665 & I $(1)$ \\
D(FPSF) & -7.0529 & -3.6752 & -2.9665 & I $(1)$ \\
\hline
\end{tabular}

The $\mathrm{R}^{2}$ and the adjusted $\mathrm{R}^{2}$ in Table 3 clearly show that, the direction of relationship among the variables is bi-directional. While debt burdens negatively affects bank performance proxied by Total Bank Branches (TBB), the result also show that domestic debt DDB, external debt (EDB) and total debt (TDB) all have total bank branches as their major introductory factor. The VAR estimates when bank sector performance is proxied by Total
Bank Lending (TBL) and Total Bank Deposit (TBD) are presented in Tables 4 and 5 respectively. The results in Tables 4 and 5 are similar to that of Table 3. The results indicate a bi-directional relationship between debt variables and the two bank sector performance indicators (TBL and TBD). The high $\mathrm{R}^{2}$ and adjusted $\mathrm{R}^{2}$ in the tables also indicate that debt burden, (domestic, external and total) impact negatively on bank performance.

Table 3. Vector auto-regression estimate total bank branches.

\begin{tabular}{lllll}
\hline & TBB & DDB & EDB & TDB \\
\hline TBB(-1) & 0.7798 & 0.0262 & -0.0472 & -0.0210 \\
TBB(-2) & 0.1895 & -0.0223 & -0.0734 & -0.0960 \\
DDB(-1) & 2.3887 & 1.9473 & 14.1864 & 16.2169 \\
DDB(-2) & -6.6764 & 1.5942 & -3.4108 & -1.7408 \\
EDB(-1) & 0.8061 & 0.2042 & 1.2672 & 1.5545 \\
EDB(-2) & -3.1345 & 1.8568 & 8.9579 & 10.8903 \\
TDB(-1) & -0.7397 & -0.3087 & -1.6475 & -2.0394 \\
TDB(-2) & 3.4676 & -1.8447 & -8.0964 & -10.0166 \\
C & 190.34 & -3.8805 & 73.4213 & 70.248 \\
$\mathrm{R}^{2}$ & 0.96 & 0.99 & 0.95 & 0.97 \\
Adj- ${ }^{2}$ & 0.94 & 0.98 & 0.94 & 0.96 \\
\hline
\end{tabular}

Table 4. Vector auto-regression estimates - Total bank lending.

\begin{tabular}{lllll}
\hline & TBL & DDB & EDB & TDB \\
\hline TBL(-1) & 0.2636 & -0.9603 & 2.2625 & 1.3034 \\
TBL(-2) & 0.8907 & 1.1995 & -4.5482 & -3.3490 \\
DDB(-1) & 0.9232 & 2.1371 & 1.3184 & 3.5228 \\
DDB(-1) & -0.9232 & 2.1371 & 1.3184 & 3.5228 \\
DDB(-2) & -0.4169 & 1.4215 & -11.0696 & -9.5822 \\
EDB(-1) & -07424 & 0.0692 & -9.2608 & -9.1232 \\
EDB(-2) & -0.5356 & 2.1862 & -1.5690 & 0.6838 \\
TDB(-1) & 0.7747 & -0.2079 & 9.1582 & 8.8821 \\
TDB(-2) & 0.5743 & -2.0947 & 2.1983 & 0.0371 \\
R $^{2}$ & -0.99 & 0.99 & 0.96 & 0.97 \\
Adj.R ${ }^{2}$ & 0.99 & 0.99 & 0.95 & 0.96 \\
\hline
\end{tabular}

Table 5. Vector auto-regression estimates - Total bank deposit.

\begin{tabular}{lllll}
\hline & TBD & DDB & EDB & TDB \\
\hline TBD $(-1)$ & 0.2608 & -03591 & 1.176 & 0.8178 \\
TBD $(-2)$ & 0.8900 & 0.4505 & -3.0420 & -2.5913 \\
DDB(-1) & -1.0682 & 2.4189 & -1.2636 & 1.2230 \\
DDB(-2) & -1.1458 & 1.448 & -11.6076 & -10.929 \\
EDB(-1) & -1.256 & 0.412 & -11.427 & -10.946 \\
EDB $(-2)$ & -1.1238 & 2.1059 & -2.435 & -0.2625 \\
TDB $(-1)$ & 1.3219 & -0.5101 & 11.242 & 10.663 \\
TDB $(-2)$ & 1.0735 & -2.076 & 3.309 & 1.1652 \\
R $^{2}$ & 0.99 & 0.99 & 0.96 & 0.97 \\
Adj. $R^{2}$ & 0.98 & 0.99 & 0.95 & 0.97 \\
\hline
\end{tabular}


Table 6. Dependent variable: TDB (Total Debt Burden).

\begin{tabular}{lll}
\hline Variable & Coefficient & Std Error \\
\hline EPS (-1) & -2.5478 & 1.1174 \\
EPS $(-2)$ & -2.7689 & 1.1425 \\
DDB (-1) & 35.053 & 58.8704 \\
DDB (-2) & 25.55 & 59.01 \\
TDB $(-1)$ & -18.97 & 58.8464 \\
TDB (-2) & -38.136 & 59.04 \\
\hline
\end{tabular}

Table 7. Dependent variable: TDB (Total Debt Burden).

\begin{tabular}{lll}
\hline Variable & Coefficient & Std Error \\
\hline EPS (-1) & -2.5478 & 1.1174 \\
EPS $(-2)$ & -2.7689 & 1.1425 \\
DDB (-1) & 35.053 & 58.8704 \\
DDB (-2) & 25.55 & 59.01 \\
TDB (-1) & -18.97 & 58.8464 \\
TDB $(-2)$ & -38.136 & 59.04 \\
\hline
\end{tabular}

\section{Impact analysis of the macro-model}

This section presents the analysis of the impact of debt variables on the banking performance indicators in the macro model. The three macro variables are the Total Bank Branches (TBB), Total Bank Lending (TBL) and the Total Bank Deposit (TBD). There are two analyses under the VAR i.e. the impulse analysis and the variance decomposition.

Impulse analysis of the VAR traces the effect of a one standard deviation shock to one of the innovation on current and future values of the endogenous variables. Variance decomposition on the other hand, decomposes the variations in the endogenous variables into their component shocks i.e. to the different innovations. Simply put, it distributes the impact in a particular variable to various sources of such impact. For clarity and convenience sake, this study adopts the variance decomposition analytical method. The results of the variance decomposition for the three macro variables are presented in Tables 8, 9 and 10.

\section{Total bank branches}

Breaking the period covered by the study into ten different stage period of about three years each,
Table 8 show that variation or shocks in Total Bank Branches (TBB) was solely caused by sustained shocks from previous shocks $(100 \%)$ in the first period. This contribution decreases gradually $88.64 \%$ in period $2,66.22$ in the $6^{\text {th }}$ period and $62.95 \%$ in $10^{\text {th }}$ period. On the other hand, the negative impact of domestic debt (DDB) on Total Bank Branches increases gradually from about $11 \%$ in the $2^{\text {nd }}$ period to $28 \%$ in the $6^{\text {th }}$ period and $29 \%$ in the $8^{\text {th }}$ and $9^{\text {th }}$ periods and fell to $28 \%$ in the $10^{\text {th }}$ period. The contribution of external debt to shocks in Total Bank Branches is very minimal moving from less them $1 \%$ in $2^{\text {nd }}$ period to about $6 \%$ in the $6^{\text {th }}$ and $8.2 \%$ in the $10^{\text {th }}$ period. The combined impact of both external and domestic debt on bank branches is negligible. It was less than $0.5 \%$ all through the 10 period.

Major inferences drawn from these results are: (i) Any shock received by Total Bank Branches is sustained over time but gradually diminishes. (ii)The shocks could have disappeared totally but for the negative impacts of domestic debt which increases over time to magnify shocks on Total Bank Branches. (iii) The impact of external debt on the general bank performance, using branches as a proxy, is negligible compared with the domestic debt impact.

Table 8. Variance decomposition for Macro - Variables

\begin{tabular}{ccccc}
\hline Variable Period & TBB & DDB & EDB & TDB \\
\hline 1 & 100 & 0.000 & 0.000 & 0.000 \\
2 & 88.64 & 10.59 & 0.75 & 0.000 \\
3 & 82.1 & 13.6 & 4.25 & 0.0008 \\
4 & 72.86 & 22.3 & 4.77 & 0.0008 \\
5 & 69.03 & 25.43 & 5.51 & 0.01 \\
6 & 66.22 & 27.83 & 5.92 & 0.019 \\
7 & 64.80 & 28.72 & 6.44 & 0.02 \\
8 & 63.83 & 29.18 & 6.95 & 0.025 \\
9 & 63.29 & 29.13 & 7.54 & 0.027 \\
10 & 62.95 & 28.82 & 8.18 & 0.028 \\
\hline
\end{tabular}




\section{Total bank lending}

As revealed by Table 9 if the period between 1975 to 2005 is divided to 10 , the decomposition of shocks received by Total Bank Lending (TBL) is as follows. In the first 3 periods, sustained shock from its own lag carry about $61 \%$. This diminishes to about $25 \%$ and $17 \%$ in the $5^{\text {th }}$ and $7^{\text {th }}$ period respectively and further reduces to $10.26 \%$ in the $10^{\text {th }}$ period. On the contrary, the contribution of domestic debt to shocks in Bank Lending increases from about $15 \%$ in the first 3 periods to about $63 \%$ in the $5^{\text {th }}$ period and more to $69 \%$ and about $71 \%$ in the $9^{\text {th }}$ and $10^{\text {th }}$ period respectively. However, the contributions of external debt to shocks received by bank lending also increases from about $6 \%$ in the first 3 period to about $11 \%$ in the $5^{\text {th }}$ period and further to $17 \%$ and $18 \%$ in the $9^{\text {th }}$ and $10^{\text {th }}$ period respectively. Just like when Total Bank Branches is used as proxy, the combined effect of both external and domestic debts on total Bank Lending is negligible and far below the separate impact. Some major inferences drawn from this result are: (i) Sustained shocks on the Total Bank Lending gradually fades away over time but not to zero. (ii) The negative impact of domestic debt on bank performance is greater when Total Bank Lending is used as proxy than when total Bank Branches is used. That means domestic debt generally affects bank lending most.(iii) The impact of external debt on bank lending is greater than that of bank branches (iv) The combined impact of debt on bank performance is not as serious as the individual impact of debt.

Thus is can be concluded that, domestic debt has hindered the expansion of bank branches; but the worse impact is on the lending ability of the banks.

Table 9. Variance decomposition of TBL.

\begin{tabular}{ccccc}
\hline Variable Period & TBL & DDB & EDB & TDB \\
\hline 1 & 100 & 0.000 & 0.000 & 0.000 \\
3 & 61.02 & 14.92 & 6.0 & 0.105 \\
5 & 25.17 & 63.49 & 11.19 & 0.13 \\
7 & 17.36 & 71.13 & 11.34 & 0.15 \\
9 & 12.61 & 69.37 & 17.72 & 0.29 \\
10 & 10.26 & 70.58 & 18.85 & 0.31 \\
\hline
\end{tabular}

\section{Total bank deposit}

From Table 10, it is shown that shocks to Total Bank Deposit (TBD) can be decomposed as follows: Sustained impact contributed about $76 \%$ in the $3^{\text {rd }}$ period while domestic debt and external debt contributed about $18 \%$ and $6 \%$ in the same period. The effect of sustained impact gradually fades away reducing to $56 \%$ and $50 \%$ in the $7^{\text {th }}$ and $9^{\text {th }}$ period respectively and further decline to about $47 \%$.
During the same period the impact of domestic debt has taken over, increasing to about $31 \%$ in the $6^{\text {th }}$ period but gradually fall back to $27 \%$ in the $9^{\text {th }}$ period and increasing again to about $32 \%$ in the $10^{\text {th }}$ period. However, the impact of external debt increases all through from about $6 \%$ in the $3^{\text {rd }}$ period to $18.5 \%$ in the $7^{\text {th }}$ period and to about $22 \%$ in $9^{\text {th }}$ period. But its impact on Total Bank Deposit is not as much as the impact of domestic debt.

Table 10. Variance decomposition of TBD.

\begin{tabular}{ccccc}
\hline Variable Period & TBD & DDB & EDB & TDB \\
\hline 1 & 100 & 0.000 & 0.000 & 0.000 \\
3 & 76.00 & 18.18 & 5.75 & 0.057 \\
5 & 56.78 & 30.98 & 12.19 & 0.05 \\
7 & 50.58 & 30.91 & 18.52 & 0.08 \\
9 & 50.41 & 27.47 & 22.02 & 0.08 \\
10 & 47.28 & 31.96 & 20.64 & 0.10 \\
\hline
\end{tabular}

A comparative analysis of impact of debt on the three proxies of general bank performance (TBB, TBL and TBD) is as follows: i) Total bank branches has a longer sustained shocks than the other two proxies; ii) Domestic debt affects the performance of banks than external debts; iii) The impact of domestic debt is great on bank branches, greater on bank deposit but greatest on bank lending ability; iv) The impact of external debt even though not as serious as domestic debt, is great on bank branches, greater on bank lending but greatest on bank deposit.

\section{Conclusion and Recommendations}

From the study, it has been established that public debt in general impacts negatively on banking sector performance and that the individual impact 
of domestic and external debt varies on the independent variables i.e. total bank lending, total bank deposit and total bank branches. Domestic debt impacts most negatively on total bank lending followed by total bank deposit and least on total bank branches. On the other hand, the impact of external debt is most negatively felt on bank deposit, followed by total bank lending and least on total bank branches. In the case of Nigeria studied here, it was found that the negative impact of domestic debt on bank performance is more than the impact of external debt.

It is recommended that while the use of borrowing to finance budget deficit and influence macroeconomic distortion can be allowed, it will be more expedient to use intelligently negotiated external funds than resort to huge domestic borrowing. The implication of this study is that domestic debt harms the Nigerian economy more.

\section{References}

Adenikinju, O (2009). Capital structure and the risk of corporate failure: Evidence from Nigeria quoted firms" in Applied Econometrics and Macroeconomic Modelling in Nigeria. Ibadan University Press, Nigeria.

Ahmad, E (1999). Retiring public debt through privatization Pakistan Journal of Applied Economics, 15(1), 1-18.

Ahmad, E \& Paul, S (1997). Foreign investment and neoclassical growth model, in readings in trade and growth, S. Paul, ed Sydney: Allen \& Unwin

Arshadi, N \& Lawrence, E. (1987). An empirical investigation of New Banks' Performance, Journal of Banking and Finance, 3, 78-96.

Borensztein, E (1990). Debt overhang, debt reduction and investment. The case of Philippines, International Monetary Fund Working Paper No WP90/77 September

Busari, D. (2001). Foreign debt and Africa's growth process, The Nigerian Journal of Economics and Social Studies, 43 (2), 179-193
Chapple, S (1990). A Sequence of errors? Some notes on the sequencing of liberalization in developing countries" UNCTAD Discussion Papers, No 31

De Young, Gron, A \& Winton, A. (2005). Risk overhang and loan portfolio decisions, Federal Reserve Bank of Chicago Working Papers

Diamond, P (1965). National debt in a neoclassical growth model, American Economic Review, 55, 1125-1150.

Fajana, F. O. (2003). Nigeria's debt crisis; UNECA Development Research Paper Series No 5. Retrieved from: www.uneca.org

Foxley, A (1987). Latin American development after debt crisis, Journal of Development Economics, 27,201-205.

Hugh, E. (1996). Banking regulation, its purpose, implementation and effects: Public affairs department, federal reserve Bank of Kansas City, USA

Imala, O. (2005). Challenges of banking sector reforms and bank consolidation in Nigeria. Bullion 29(2) April-June.

Iyoha, M. A. (1996). External debt and economic growth in Sub-Sahara African Countries: An econometric study. Retrieved from: www.researchnetwork.

Levine, R \& Relnet, D. (1992). A sensitivity analysis of cross country growth regressions American Economic Review, 82.

Ncube, M \& Senbet, L.W (1994). Perspective in financial deregulation and liberalization in Africa Under Incentive Problems and Asymmetric Information, Paper presented at the AERC Research Workshop, Nairobi, 2-8 December.

Oyejide, T (1985) Nigeria and the IMF. Heineman Educational Books, Ibadan, Nigeria.

Samuelson, P. A (1958). An exact consumption-loan model with or without the social contrivance of money in Journal of Political Economy, 66.

Santos, J. A.C (2000). Bank capital regulation in contemporary banking theory: A review of literature, BIS Working Papers, No 90, Bank for International Settlements: Monetary Economics Department, Basel Switzerland

Soludo, C.C (2001). Debt, poverty and inequality, towards an exit strategy for Nigeria and Africa, CBN Economic and Financial Review, 24(4).

Van den Hewel, S.J (2002). Does bank capital matter for monetary policy transmission" Economic Policy Review FRBNY May 2002

Willis, R. J. (1983). A theory of the equilibrium interest rate in an overlapping generations model: Life cycle, Institutions and Population Growth, Chicago, Illinois; Economic Research Center, NORC, Discussion Paper, 85(8). 